\title{
Investigation of the Self-efficacy Beliefs in Teaching Science and Attitudes towards Teaching Profession of the Candidate Teachers
}

\author{
Gökhan Uyanık \\ Faculty of Education, Kastamonu University, Kastamonu, Turkey
}

Copyright $\odot 2016$ by authors, all rights reserved. Authors agree that this article remains permanently open access under the terms of the Creative Commons Attribution License 4.0 International License.

\begin{abstract}
The aim of this study is to investigate the attitudes of the primary school teacher candidates towards teaching profession and self-efficacy beliefs in teaching science. The research was conducted with a survey model. The sample of the study consisted of 182 teacher candidates who were studying at the 2015-2016 spring term from Kastamonu University, at Faculty of Education in Elementary Teacher Training program at the first and fourth years of university level. Scale of Self-Efficacy Beliefs towards Science Teaching and Scale of Attitudes towards to Teaching Profession were used as data gathering tools. Independent t-testing and Pearson's Correlation Coefficients have been used in analyzing the data. According to findings, there was a significant difference between the freshman and senior students on the self-efficacy scaling related to teaching the science in favor of the senior students. In addition, it was also been discovered that there was also statistical difference in favor of the senior students compared to the freshman students on attitude scale towards to the teaching profession. It has also found that there was a statistical intermediate positive relationship between the self-efficacy of teaching the science and the attitudes towards teaching profession at the teacher candidates, who were studying at the first year of the university. However, it was discovered that there was a higher probability positive relationship between the self-efficacy beliefs and the attitudes to the teaching profession of teacher candidates, who were at the last year of the university.
\end{abstract}

Keywords Teaching Science, Self-efficacy, Primary School Teacher Candidates, Attitude

\section{Introduction}

The teachers' training of successful students in the field of sciences is related to the having higher rate of positive attitudes towards teaching science and the candidate's self-efficacy beliefs about teaching science [1]. The candidates of primary school teachers have to have a higher rating of positive self-efficacy feelings in order to improve themselves within the process of teaching the science.

As a concept, self-efficacy belief/feeling was used by Bandura for the first time. According to [2], as it is understood within the social-learning theory, self-efficacy could be defined as to organize the needed activities to activate the performance of the people on specific fields and views of these people considering their own self-efficacy in order to perform those activities. That is, self-efficacy is the personal/individual view of a person considering himself as a successful individual in front of a specific problem and how to overcome this problem [3]. Self-efficacy, which means to the self-assessment of people on dealing with a problem and their personal feelings in being successful, might give important clues on how some specific abilities or behaviors are understood in the educational processes and how they are perceived by the individuals. The personal judgments of the teachers and teacher candidates about their personal abilities and skills on dealing with the problems in overcoming these problems that they have faced in their educational and teaching processes have an important role in their qualified teaching [4].

Aston defines the self-efficacy of teacher in terms of the teacher's ideas of himself that she could affect her students' capacity in order to perform the needed behaviors to become a successful teacher and to make the students feel faith in themselves. Self-efficacy toward to teaching science can be defined as the judgments and feelings of the teachers considering that they could teach sciences in an efficient and successful way and they could improve the success of their students [6]. The teachers, who have a high rate of self-efficacy, tend to use different teaching methods and they are inclined to do research more in order to develop their teaching, and they use more student-centered teaching/learning strategies [7]. Teachers with the low rate 
of self-efficacy are used to doing their teaching in teacher-centered way and they continue their teaching just by reading the text/course books [8]. Chan has indicated that the teachers with the higher rate of self-efficacy are teaching in a more effective way and they are more relaxed in their lessons compared to the teachers that have a low rate of self-efficacy in his research.

One of the most important factors shaping the life of the individual is his/her profession. Selecting a proper profession and having a positive attitude to the job could make the individual happy, besides contributing the community development [10]. Being a vital life-factor resulting from the division of labor in social life, the profession/job is also crucial for the continuity of the social life [11]. The individual gets a special position with the help his personal job and he earns his life and builds his future based on his profession. The job also affects the individual's character in a great extent [12]. The appropriate job with the self-character enriches the personal character, whereas the inappropriate profession might pose serious problems for the individual. Similarly, it is expected that the individuals, who have the jobs appropriate for their characters, will be more successful and efficient in their life, while the other individuals; who have the inappropriate jobs for their characters, will have a greater risk in experiencing personal conflicts and dissatisfaction [13]. In this context, it is critical to analyze the attitudes of the teacher candidates regarding the teacher profession and in the light of the findings the needed precautions are to taken [14].

Teaching is a term expressing a position at educational institutions; teaching consists of a set of behaviors expected by this institution and it represents the status, duty and the relationship of the educational institution [15]. Yilmaz stated that teaching is a dynamic job and argues that the teacher should not confine herself along her job-life to the achievements of just one foundation that's worked for. Furthermore, Yilmaz claimed that the practice of this profession is important as its content, and they state that it's a prerequisite to have a positive attitude towards being a teacher in order to overcome the problems of the profession, since it is not possible to teach the content/skills just by having knowledge on the subject.

The personal preferences of the teacher are one of the crucial factors in affecting the students' development. On that note, it is possible to think that there is a positive relationship between teacher's focusing on her work and the student's learning by taking her as a model. In short, the quality of the teacher's behaviors is one of the important factors effective in the achievement of the objectives of the educational system. The most parts of the research done in this field focuses on that the knowledge, skills, abilities and behaviors of the teacher candidates, which are acquired before tutoring, are all important factors in education. This situation arises from the fact that the roles of teacher and the students have all become different with the effect of the last changes all around the world. The classical teacher role of the past education system, which is strict, hard-disciplined, firm mannered and having the only right to talk in the classroom, is have to share the responsibility of the learning environment with her learners as a consequence of the last learner-centered education approach of the modern education system [10].

Modern education approaches highlight the importance of discovering the personal attentions and requirements during the choice of profession and the individual should select the professions that will suit himself most, an these approaches also emphasize the importance of developing positive attitudes towards to the individual profession. For the individual, it is important to behave in realistic way in selecting the jobs; in other words, it is very important to select a proper job in accordance with the personal values, abilities, chances, skills and attention [10]. In this sense, the role of the attitude about the job is not negligible.

The attitude of the profession (vocational attitudes) determines the ongoing success of the job. In this case, the possibility of success of the teachers loving their job will be higher than the rate of success of the other teachers [17]. To have a professional awareness seems to be very important for the teacher candidates by developing the positive attitudes about the job. It is important for provide the chances for teacher candidates to acquire the Professional consciousness within the first years of pre-service of education [18]. It is expected from the teachers to gain the positive affective skills besides having the skills and abilities required by the teacher profession. One of the important elements of affective properties, the attitude is one of the frequently used concepts of the educational studies [19]. As having a determiner roles in behaviors, the attitudes are worth examine while analyzing the behaviors of the individuals. Attitude is a tendency that represents the personal interests, feelings and emotions about a psychological object and it is attributed to an individual [20]. The attitudes are evaluative expressing about the objects, people or events both in a positive or negative way, and an attitude means how a person feels about an object [21].

On the light of the literature review, the relationship between the self-efficacy of the teacher candidates on teaching sciences and the alternative conceptualization of the classroom teachers with regards to the sciences [22]. The judgments of the classroom teachers on the science subject and teaching the sciences $[23,24,25]$ effect of the science teaching main courses on the self-efficacy of the teacher candidates [26, 27]. In addition, the studies, which included the self-efficacy perceptions in teaching the sciences of the teacher candidates and the factors playing a role in their attitudes of being a teacher, take place within this literature $[24,28,29,30,31,32,33,34]$. Teachers with low content knowledge have a higher rate of self-efficacy perception compared to the other teachers, who have a stronger self-efficacy perception of being a teacher. They concluded that the teachers with the high rate of self-efficacy have a tendency to set up a more learner-centered classroom environments by using inquiring methods, and they claimed that this kind of teachers have achieved a greater level of 
success in solving the students problems, and they claimed that these teachers have a great amount of content knowledge about the developmental levels of the students besides believing in themselves.

The teacher candidates might have positive or negative attitudes about the private teaching. Their level of self-efficacy regarding to teaching sciences might be high or low. Consequently, it is required to determine their attitudes of being a teacher and their perception of self-efficacy, and it is important to examine how they have developed these attitudes and beliefs. The limitations of pre-service qualification in teacher training could be analyzed if the attitudes of the teachers and their beliefs about their self-efficacy related to the main educational sciences are determined by the scientific studies. In this way, some solutions could be found for the detected drawbacks. This study is essential in investigating the attitudes of the teachers, as well as detecting the level of the last year students' self-efficacy in teaching the sciences. The aim of this study is to examine the attitudes and self-efficacy levels of the students, who are studying at the first and last year of the education department at undergraduate level. The following questions were asked to achieve this aim:

1) Is there a significant difference in the self-efficacy levels in teaching sciences of the students from the various years?

2) Is there a significant difference in the attitudes towards teaching profession between the different-year students?

3) What kind of relationship exists between the attitudes and the self-efficacy beliefs of the candidate teachers from the different years with regards to teaching science?

\section{Materials and Methods}

\subsection{Model of Research}

This research was conducted by survey model. The survey studies are called as researching the participants' views or opinions are determined and these studies have been conducted mostly on large scale of taking samples [35].

\subsection{Sample of Research}

The population of the research consisted of teacher candidates, who were studied at the Elementary Teaching undergraduate program in the Faculty of Education of Kastamonu University in the spring term of 2015-2016 academic year. The sampling consisted of 182 teacher candidates total from the first and fourth grade of the students selected by the purposeful sampling method. 87 of the teacher candidates studies at the first grade, while the rest 95 candidate teachers were at the fourth (last) grade.
The descriptive statistics of the sample is seen at the Table 1.

Table 1. Descriptive statistics the sample of research

\begin{tabular}{ccc}
\hline Grade Level & $N$ & $\%$ \\
First Year & 87 & 47,8 \\
Fourth Year & 95 & 52,2 \\
Total & 182 & 100 \\
\hline
\end{tabular}

As it is seen in the Table 1, 47,8\% percent of the sampling population consists of elementary teacher candidates at the first year level of the undergraduate level, while the rest $52,2 \%$ percentage of it includes the teacher candidates from the fourth year.

\subsection{Data Gathering Tools}

Developed by the Riggs \& Enochs and adapted into Turkish [37] Scale of Self-efficacy Beliefs of the Primary School Teacher Candidates in Teaching Science and the Attitude Scale towards to Teaching Profession developed by [15] were used in this research as data collection tools.

The self-efficacy beliefs scaling of the primary school teacher candidates in teaching the science are of the 5 point likert scale type. Comprised of 23 articles originally this scale has been adapted by 21 articles in Turkish by [37] took its final shape. The Turkish version of this scaling has been performed to the 279 teacher candidates studying at elementary teaching program at different 3 universities in Turkey. According to the results of the factor analysis, this scale has been determined as in two-dimensional form like it is in its original form. As being the first dimension of the scale, there were 13 factors at the factor of Teaching Sciences Self-efficacy Belief, consisting of 5 positive and 8 negative articles forming the total 13 factors. There were 8 articles at total, as being 7 positive and one negative factor at the factor of Result Expectation in Teaching Sciences as the second dimension of the factor. Degree of reliability of the first factor was calculated as .89 at the original form of the scale, while it was calculated as .69 as for the second factor. The reliability degree in relation to the overall scaling was determined as .85 . For this study, the degree of reliability for the first dimension of the scale was calculated as .87 , while this rate was found as .70 for the second factor. For the overall scale, the degree of reliability was calculated as .83 . The most positive expression in this scaling was scored as 5 points. The highest score of this scale was 105 points. The most negative expression of the scale was scored as 1 point; in this scaling the lowest score could be 21 points.

The attitude scale towards to the teacher profession consists from 34 articles reflecting the attitudes to the teaching. This scale was developed by [15] as in the type of 5 points Likert scale in undimensional form. The controlling form of this scale has been applied to the 449 students from 11 different teaching undergraduate programs by [15]. As a result of the principal component analysis carried out in relation with the construct validity of the scale it is found 
that the value of factor loading of the first factor, which consists of 34 article, was between .71 and .41 , while the total variance of the factor was $30 \%$. The total point of the scale and individual test correlation of the each article have been examined and it was found that the correlational values of the articles are in the range of .74 and .42 . The validity of scaling value was determined as .89 and the internal consistency coefficients of the scale was calculated as .93 as in the original form by [15]. For this study, the validity of the scaling was evaluated as .84 and the internal consistency coefficient was analyzed as .95 . The higher scores mean that more positive attitude and the lower scores done at this scale means negative attitudes towards the profession of teaching. The most positive answer was evaluated as 5 points, while the most negative response assumed as 1 point from the attitude scale, which is consisting of 34 articles. In this way, the highest score was 170, while the lowest score was 34 for this testing.

\subsection{Implementation}

The data were collected by the researcher from the teacher candidates who were studying at the Elementary Teacher Training Department in the first and fourth grade at Faculty of Education in Kastamonu University in the 2015-2016 academic year spring term. Data were collected through the questionnaires distributed to the participants by the researcher in their classes.

\subsection{Data Analysis}

The data were analyzed by using the SPSS 21.0 statistical package software. During the analysis of the data independent t-test was used. In addition to this, Pearson Correlational Coefficient was calculated for the relational analysis. The data were tested at $\mathrm{p}<.01$ significance level.

\section{Results of Research}

\section{Results about first sub-problem}

In order to examine the considerable difference level between the teacher candidates as for the different graders in relation to the self-efficacy belief scaling towards to teaching sciences, independent $\mathrm{t}$-test was applied. The results of the independent t-testing are listed at Table 2.

Table 2. Independent t-test results of different grade levels candidate teachers' self-efficacy beliefs towards science teaching scale scores

\begin{tabular}{ccccccc}
\hline Group & $\mathrm{N}$ & $\mathrm{M}$ & $\mathrm{SD}$ & $\mathrm{df}$ & $\mathrm{t}$ & $\mathrm{p}$ \\
$\begin{array}{c}\text { First } \\
\text { Grade }\end{array}$ & 87 & 47.12 & 3.52 & & & \\
$\begin{array}{c}\text { Fourth } \\
\text { Grade }\end{array}$ & 95 & 76.18 & 4.44 & 180 & 48.57 & $.000^{*}$ \\
\hline$* \mathrm{p}<.01$ & & & & & & \\
\hline
\end{tabular}

In Table 2, the self-efficacy beliefs results in teaching science of the first grade and fourth grade teacher candidates, who were studying elementary teacher training department at the undergraduate level, were compared. After the independent t-test was applied, it was found that there was a statistically significant difference between the first and fourth grade students in favor of the fourth year teacher candidates $\left(\mathrm{t}_{(180)}=48.57, \mathrm{p}<.01\right)$. This finding could be interpreted as the self-efficacy beliefs level of the fourth year teacher candidates are more positive than the first year candidates.

\section{Results about second sub-problem}

In order to examine the considerable difference level between the teacher candidates as for the different graders in relation to the attitudes towards teaching profession, independent t-test was applied. The results of the independent t-test are listed at Table 3 .

Table 3. Independent t-test results of different grade levels candidate teachers' attitudes towards teaching profession scale scores

\begin{tabular}{ccccccc}
\hline Group & $\mathrm{N}$ & $\mathrm{M}$ & $\mathrm{SD}$ & $\mathrm{df}$ & $\mathrm{t}$ & $\mathrm{p}$ \\
$\begin{array}{c}\text { First } \\
\text { Grade }\end{array}$ & 87 & 125.94 & 4.77 & & & \\
$\begin{array}{c}\text { Fourth } \\
\text { Grade }\end{array}$ & 95 & 137.89 & 4.96 & 180 & 16.51 & $.000^{*}$ \\
\hline
\end{tabular}

$*_{\mathrm{p}}<.01$

The attitudes towards teaching profession of the first grade and fourth grade teacher candidates, who were studying elementary teacher training department at the undergraduate level, were compared in Table 3. After the independent t-test was applied, it was found that there was a statistically significant difference between the first and fourth grade students in favor of the fourth year teacher candidates $\left(\mathrm{t}_{(180)}=16.51, \mathrm{p}<.01\right)$. This result could be interpreted as the attitudes towards teaching profession of the fourth grade teacher candidates are more positive than the first grade candidates.

\section{Results about third sub-problem}

In order to examine the relationship of the self-efficacy levels in teaching science and attitudes regards to the teaching profession of the different graders of the teacher candidates, Pearson Correlational coefficients were calculated. The related findings are listed at Table 4.

According to Table 4, there was a middle level of significant relationship between the self-efficacy beliefs in teaching science and the attitudes towards teaching profession between the first grade elementary teacher candidates $(r=0.682, p<.01)$. Furthermore, it has been found that there was a high level positive and meaningful relationship between the self-efficacy beliefs and the attitudes of teaching profession for the last/fourth graders of the elementary teacher candidates, $(\mathrm{r}=0.813, \mathrm{p}<.01)$.

By examining these findings, it can be said that there was a direct positive correlation between the self-efficacy beliefs level in teaching sciences and the attitudes towards to the teaching profession for both the first and fourth grade teacher candidates. In other words, the more the teacher 
candidates have more positive attitudes towards being a teacher, the more their self-efficacy levels of teaching sciences rises.

Table 4. The relationship between the different grade levels candidate teachers' self-efficacy beliefs in teaching science and attitudes towards teaching profession

\begin{tabular}{ccccccc}
\hline $\begin{array}{c}\text { Grade } \\
\text { Level }\end{array}$ & Scale & $\mathrm{N}$ & $\mathrm{M}$ & $\mathrm{SD}$ & $\mathrm{r}$ & $\mathrm{p}$ \\
\hline $\begin{array}{c}\text { First } \\
\text { Grade }\end{array}$ & SSBST & 87 & 47,12 & 3,52 & $.682^{* *}$ & .000 \\
& SATP & 87 & 125,94 & 4,77 & & \\
\hline & Scale & $\mathrm{N}$ & $\mathrm{M}$ & $\mathrm{SD}$ & $\mathrm{r}$ & $\mathrm{p}$ \\
\hline $\begin{array}{c}\text { Fourth } \\
\text { Grade }\end{array}$ & SSBST & 95 & 76,33 & 4,82 & $.813^{* *}$ & .000 \\
& SATP & 95 & 137,89 & 4,96 & & \\
\hline
\end{tabular}

${ }^{*} \mathrm{p}<.01$

SSBST: Scale of Self-efficacy Beliefs towards Science Teaching

SATP: Scale of Attitudes towards Teaching Profession

\section{Discussion and Conclusions}

In this research, the self-efficacy beliefs levels of teaching science and the attitudes towards teaching profession of different graders teacher candidates, who study at elementary teacher training undergraduate program, were investigated. In terms of self-efficacy beliefs levels in teaching science, a significant difference has been found in favor of the fourth grade teacher candidates compared to the first grade students. According to this result, the self-efficacy belief levels in teaching science of the fourth grade students were higher than the first grade teacher candidates. This result has shown a similarity with the related studies [38, 23, 24, 39, 34, 7].

For the new teachers, developing their self-efficacy in teaching science is a prequel in order to have achieved a more positive attitude towards the Life Sciences courses [40]. Providing the learner environments, in which the learning takes place by positive experiences, is essential in order to train questioner and sensitive individuals. In this context, the teachers need to have an interest for the course themselves in order to train the concerning individuals about the life sciences [26]. It could be said that the Science and Technology Teaching courses at the third year of the Elementary Teaching program at the undergraduate programs is an important tool serving for this purpose. Thus according the result of this research, the self-efficacy beliefs levels of fourth grade teacher candidates in teaching science are much higher. It could be said that this situation arises from the fact that the courses of Science and Technology Teaching at the third year level in the undergraduate program of the classroom teacher candidates. Consequently, the teaching of these courses related to the Science and Technology Teaching in a more effective way by new learning methods and techniques could contribute to this situation in a great extent. The studies of this field have shown that the teachers reflect their individual ideas and opinions related to the life sciences [8]. In this context, the teacher candidates must have higher self-efficacy level in teaching science [38]. When the teacher candidates start to teach in this field, their success level in teaching, selecting the appropriate teaching methods and techniques and their relationship with their students will be more effective if they have a high self-efficacy level in teaching science [41, 42]. The self-efficacy beliefs level in teaching science of the teacher candidates could only be achieved in the faculties of education [43]. In order to have a higher level of self-efficacy in teaching than the normal standards, the usage of application, which take the individual differences, might be useful for the purpose [38].

In this research it was found that there was a huge statistically positive difference in favor of the last year students/teacher candidates compared to their first grade counterparts in terms of having attitudes towards teaching profession. According to this result, it could be said that the attitudes towards the teaching profession of the fourth grade teacher candidates are higher than the first year students. This result supports other related studies [44, 45]. However on the contrary to these results, $[46,47,14]$ have found that there has been no significant effect of the year/grade level of students in terms of their attitudes towards the teaching profession. The higher levels of the fourth grade students both in the self-efficacy and having positive attitudes, when compared to the previous year students, could arise from the courses they have taken all their program in 4 years education. However, School Experience and Practice Teaching courses that are given at third and fourth years at undergraduate programs might be affective for the fourth year teacher candidates to have a more positive attitude towards teaching profession.

Moseley \& Utley stated that for the new teachers developing their self-efficacy beliefs in teaching science it a prequel in order to have achieve a more positive attitudes towards the Science courses. From this perspective, the possible relationships of the self-efficacy levels in teaching science and the attitudes of the teacher candidates were investigated within this research. According this situation, there was a middle level positive and significant relation between the self-efficacy beliefs levels and attitudes towards teaching profession of the first grade teacher candidates. However, the relationship between the self-efficacy beliefs and having positive attitudes of the fourth grade students were analyzed much more higher.

Within the light of these results, it can be claimed that the teacher candidates, who have increased their levels of self-efficacy beliefs in teaching science, have also managed to have more positive attitudes of becoming a teacher. The importance of the education delivered to the teacher candidates during their undergraduate education process is very crucial. Particularly, the vocational courses related to teaching and pedagogical courses have a great importance on their learning process of being a teacher. These kinds of courses could form the base of teaching.

The application should be performed in order to make the 
teacher candidates especially in terms of pedagogical courses during their undergraduate program. Teacher candidates should be activated in the courses related to their profession. The courses, which are by the active involvement of the students in the science courses, will be particularly beneficial to them in developing a higher self-efficacy level in teaching science. This situation might contribute to the teacher candidates in having a more positive attitude of being a teacher, by experiencing teaching in their practice courses.

The teacher candidates, who have a more positive attitude, will be effective in training the new generation in a better way. On this context, the academicians of the educational faculties have a crucial responsibility. The learner centered/experience based courses should be given to the teacher candidates. Two way communications should be provided, and the opinions of the undergraduate students are to be considered. In the scope of the courses as school experience and practice teaching, the courses are to be done even in communication with some village schools, and the collaboration with the teacher teaching at these kinds of schools. By this way, the primary school teacher candidates could gain different experiences before teaching.

\section{REFERENCES}

[1] Tschanen-Moran, M., Woolfolk-Hoy, A., \& Hoy, W. K. (1998). Teacher efficacy. Its meaning and measure. Review of Educational Research, 68 (2), 202-248.

[2] Bandura, A. (1986). Social foundations of thought and action: a social cognitive theory. Englewood Cliffs, NJ: Prentice-Hall.

[3] Tuckman, B. W. (1991). Educational psychology. From theory to application. Florida: Harcourt Brace Jovanovich, Inc.

[4] Özdemir, S. M. (2008). Investigation of the elementary teacher candidates' self-efficacy beliefs towards the teaching process for different variables. Educational Administration: Theory and Practice, 54, 277-306.

[5] Aston, P. T. (1984). Teacher efficacy: A motivational paradigm for effective teacher education. Journal of Teacher Education, 35(5), 28-32.

[6] Özkan, Ö., Tekkaya, C. \& Çakıroğlu, J. (2002). Understanding the science concepts of science teacher candidates' levels, attitudes towards science education and self-efficacy beliefs. V. Science and Mathematics Education Congress, 16-18 September 2002 Ankara: Middle East Technical University.

[7] Yıldız-Duban, N., \& Gökçakan, N. (2012). Classroom teacher candidates' attitudes towards teaching profession and self-efficacy towards science teaching. Çukurova University, Institute of Social Science Journal, 21 (1), 267-280.

[8] Plourde, L. A. (2002). The influence of student teaching on pre-service elementary teachers' science self-efficacy and outcome expectancy beliefs. Journal of Instructional
Psychology, 29 (4), 245-252.

[9] Chan, D. W. (2003). Multiple intelligences and perceived self-efficacy among Chinese secondary school teachers in Hong Kong. Educational Psychology, 23(5), 521-533.

[10] Bozdoğan, A. E., Aydın, D., \& Yıldırım, K. (2007). Attitudes towards teaching profession of teacher candidates. Ahi Evran University Kurşehir Faculty of Educational Journal, 8(2), 83-97.

[11] Sönmez, V., Senemoğlu, N., Alkan, C., Bircan, I., Karakütük, K., \& Yanpar, T. (2000). Entry into the teaching profession. Ankara: Anı Publishing.

[12] Aslan, D., \& Köksal-Aksoy, A. (2006). Examining attitudes towards the teaching profession and professional self-esteem of pre-school teachers. Cukurova University Journal of the Institute of Social Sciences, 15(2), 51-60.

[13] Arıcak, T., \& Dilmaç, B. (2003). Self-esteem in terms of a number of variables, examination of vocational guidance and counseling student self-esteem levels. Trakya University Journal of Social Sciences, 3(1), 1-8.

[14] Özder, H., Konedral1, G., \& Zeki-Perkan, C. (2010). Examining the attitudes of prospective teachers teaching profession in terms of various variables. Theory and Practice in Educational Administration, 16 (2), 253-275.

[15] Üstüner, M. (2006). Reliability and validity of the scale of attitude towards the teaching profession, Theory and Practice in Educational Administration, 45, 109-127.

[16] Yilmaz, H. (1996). Measurement and evaluation in education (1. Ed.). Istanbul: Öz Eğitim Publishing.

[17] Şenel, H. G., Demir, İ., Sertelin, Ç., Kılıçaslan, A., \& Köksal, A. (2004). The relationship between attitudes towards the teaching profession and personality traits. Educational Research, 15 (4), 99-109.

[18] Şimşek, H. (2005). Secondary education teacher for non-thesis program, students continued their attitudes towards the teaching profession. 100. Year University Electronic Journal of Education, 2, 1-26.

[19] Başbay, M., Ünver, G., \& Bümen, N. T. (2009). Secondary education teacher graduate thesis students' attitudes towards the teaching profession: A longitudinal study. Theory and Practice in Educational Administration, 15(59). 345-366.

[20] Kağıtçıbaşı, Ç. (1999). New human and people. İstanbul: Evrim Publishing.

[21] Robbins, S. (1994). Fundamentals of organizational behavior. (Trnslt. S. A. Öztürk). Eskişehir: ETAM Printed Publications.

[22] Schoon, K. J., \& Boone, W. J. (1998). Self-efficacy and alternative conceptions of science of pre-service elementary teachers. Science Education, 82 (5), 553-568.

[23] Hazır-B1kmaz, F. (2006). Views on the effective science and self-efficacy beliefs in science teaching. Eurasian Journal of Educational Research, 25.

[24] Morrell, P., \& Carroll, J. (2003). An extended examination of pre-service elementary teachers' science teaching self-efficacy. School Science and Mathematics, 103 (5), 246-251. 
[25] Tosun, T. (2000). The beliefs of pre-service elementary teachers toward science and science teaching. School Science and Mathematics, 100 (7), 376-382.

[26] Palmer, D. H. (2006). Durability of changes in self-efficacy of pre-service primary teachers. International Journal of Science Education, 28 (6), 655-671.

[27] Watters. J. J., \& Ginns, I. S. (2000). Developing motivation to teach elementary science: Effect of collaboration and authentic learning practices in pre-service education. Journal of Science Teacher Education, 11 (4), 301-321.

[28] Morgil, İ., Seçken, N., \& Yücel, A. S. (2004). Some of the variables to be examined in terms of chemistry teacher candidates' self-efficacy beliefs. Balıkesir University Journal of the Institute of Science, 6 (1), 62-72.

[29] Andrew, S. (1998). Self-efficacy as a predictor of academic performance in science. Journal of Advanced Nursing, 14(6), 436-442.

[30] Lent, R. W., Brown, S. D., \& Larkin, K. C. (1984). Relation of self-efficacy expectations to academic achievement and persistence. Journal of Counseling Psychology, 31, 356-362.

[31] Yaman, S., Cansüngü, Ö., \& Altunçekiç, A. (2004). A study on examining the level of self-efficacy beliefs of science teacher candidates. Turkish Journal of Educational Sciences, 2 (3), 355-364.

[32] Britner, S. L. \& Pajares, F. (2006). Sources of science self-efficacy beliefs of middle school students. Journal of Research in Science Teaching, 43(5), 485-499.

[33] Hamurcu, H. (2006). Self-efficacy beliefs towards science teaching of primary school teacher candidates. Educational Research, 24, 112-122.

[34] Küçükyılmaz, A., \& Duban, N. (2006). Opinions on the measures to be taken in order to increase self-efficacy beliefs of science teaching of classroom teacher candidates. 100. Year University Journal of Education, 3(2), 1-23.

[35] Fraenkel, J. R., \& Wallen, N. E. (2006). How to design and evaluate research in education. (6th Ed). New York: McGraw-Hill International Edition.

[36] Riggs, I. M., \& Enochs, L. G. (1990). Toward the development of an elementary teacher's science teaching efficacy belief instrument. Science Education, 74(6), 625-637.
[37] Hazır-Bıkmaz, F. (2002). In science teaching self-efficacy scale. Education Science and Applications, 1(2), 197-210.

[38] Berkant, G. H., \& Ekici, G. (2007). Evaluating the relationship between classroom teachers in science education teacher candidates' self-efficacy levels and types of intelligence. Cukurova University Journal of Institute of Social Sciences, 16(1), 113-132.

[39] Kaya, S. (2013). Classroom teacher candidates' science teaching self-efficacy beliefs of the candidates, depending on the course of science education changes. Mustafa Kemal University Journal of the Institute of Social Sciences, 10 (21), 55-69.

[40] Moseley, C., \& Utley, J. (2006). The effect of an integrated science and mathematics content-based course on science and mathematics teaching efficacy of pre-service elementary teaching. Journal of Elementary Science Education, 18 (2), $1-12$.

[41] Anderson, A. M., Dragsted, S., Evans, R. H., \& Sorensen, H. (2004). The relationship between changes in teachers' self-efficacy beliefs and the science teaching environment of Danish first-year elementary teachers. Journal of Science Teacher Education, 15, 25-38.

[42] Appleton, K., \& Kindt, I. (2002). Beginning elementary teachers' development as teachers of science. Journal of Science Teacher Education, 21, 155-168.

[43] Morrisey, J. T. (1981). An analysis of studies on changing the attitude of elementary student teacher toward science and science teaching. Science Education, 65 (2), 157-177.

[44] Özbek, R., Kahyaoğlu, M., \& Özgen, N. (2007). Assessment of candidate teachers' attitudes towards the teaching profession. Journal of Social Sciences, 9 (2), 221-232.

[45] Çapa, Y., \& Çil, N. (2000). Examining the attitudes of prospective teachers teaching profession in terms of different variables. Hacettepe University Journal of Education, 18, 69-73.

[46] Pehlivan-Baykara, K. (2008). A study on the classroom teacher candidates' socio-cultural characteristics and attitudes towards the teaching profession. Mersin University Journal of Education, 4 (2), 151-168.

[47] Terzi, A. R., \& Tezci, E. (2007). Necatibey faculty of education students' attitudes of the teaching profession. Theory and Practice in Educational Administration, 52, 593-614. 